\title{
Short-term effect of cyproterone acetate on testicular FSH binding in immature rats
}

\author{
P. S. Brown and P. J. O'Shaughnessy \\ Department of Pharmacology, The Medical School, University of Bristol, Bristol BS3 ITD, \\ U.K.
}

\begin{abstract}
Summary. Male rats, aged 19 days, were injected with $1 \mathrm{mg}$ cyproterone acetate, an antiandrogen, and killed $24 \mathrm{~h}$ later. In 9 out of 10 experiments this increased the apparent FSH-binding capacity by testicular tissue in vitro. In 4 out of 5 similar experiments, injection of $500 \mu \mathrm{g}$ testosterone propionate caused a significant reduction in FSH binding. Observed changes were small but this does not preclude the possibility that androgens contribute to the physiological control of FSH receptor numbers.
\end{abstract}

\section{Introduction}

Both FSH and androgens apparently influence the production of androgen-binding protein by the Sertoli cells (Elkington, Sanborn \& Steinberger, 1975; Louis \& Fritz, 1979) and their inter-relationship is of interest. We have therefore injected rats with the anti-androgen, cyproterone acetate, and studied the subsequent short-term binding of FSH to the testicular receptors in vitro. Longer term effects have been reported by Neumann, Diallo, Hasan, Schenck \& Traore (1975).

\section{Materials and Methods}

The animals and general procedures for studying the binding of iodinated rat FSH were as described previously (O'Shaughnessy \& Brown, 1978) except that homogenates were of total testis tissue. Male Porton rats, aged 19 days, were weaned and injected subcutaneously with 1 mg cyproterone acetate (Schering) in $0.1 \mathrm{ml}$ arachis oil containing benzyl benzoate or with the vehicle alone. In subsidiary experiments, rats of this age were injected with $500 \mu \mathrm{g}$ testosterone propionate in oil containing ethyl oleate or with the vehicle. Rats were killed $24 \mathrm{~h}$ later and blood was pooled within treatment groups for radioimmunoassay of serum FSH by using the NIAMDD kits and recommended method as previously described (Sharpe \& Shahmanesh, 1974): the method fails to detect FSH in the serum of hypophysectomized rats.

In one series of experiments, homogenates were made from the pooled testes of all animals in the treatment group, either at a fixed weight of tissue $/ \mathrm{ml}$ or at a fixed volume/testis. Specific binding of ${ }^{125}$ I-labelled rat FSH was measured during $1.5 \mathrm{~h}$ at $37^{\circ} \mathrm{C}$ in a Tris buffer, $\mathrm{pH} \mathrm{7.5}$, at two or more concentrations of homogenate. Measurements were at least in triplicate and each incubation tube was paired with another to measure non-specific binding ( $O$ 'Shaughnessy \& Brown, 1978). In the other series of experiments, a separate homogenate was made for each rat at a fixed volume/testis: these homogenates were tested in triplicate at one concentration of homogenate to give a single value for specific binding for each animal. 


\section{Results}

\section{Binding to homogenates of pooled tissue from rats treated with cyproterone acetate}

Table 1 shows the results of Exps $1-4$. The percentage of added ${ }^{125}$ I-labelled rat FSH bound by the lowest concentration of homogenate varied between experiments. Analysis of variance showed that in Exps 1 and 3 the specific binding of FSH was significantly $(P<0.01)$ greater per unit weight of tissue after cyproterone acetate treatment. This suggested an increase in total testicular binding capacity as the weight of tissue recovered from each testis was not apparently altered by cyproterone acetate treatment. For Exps 1-7, 59.3 $\pm 5.2 \mathrm{mg}$ testicular tissue was recovered from controls and $58.4 \pm 3.4 \mathrm{mg}$ from those treated with cyproterone acetate. Similarly, there was no significant change in serum FSH levels: in Exps 2-4, 6 and 7 values in rats treated with $1 \mathrm{mg}$ cyproterone acetate $24 \mathrm{~h}$ previously, expressed as a percentage of that in controls (with 95\% fiducial limits), were 108 (97-121), 84 (67-105), 98 (78-122), 95 (75-121) and $92(72-116)$, respectively.

In Exps 5-7 (Table 1) maximum binding capacity per testis was increased by treatment with cyproterone acetate and there was no apparent change in the slope of the lines to suggest any change in affinity, $K_{\mathrm{d}}$ ranging from 7.9 to $9.8 \times 10^{-11} \mathrm{M}$.

Table 1. Binding of FSH by homogenates prepared from pooled testes of immature rats (at least $3 /$ group) treated with $1 \mathrm{mg}$ cyproterone acetate (CPA) or with vehicle alone

(controls)

\begin{tabular}{|c|c|c|c|c|c|c|}
\hline \multirow[b]{4}{*}{ Exp. } & \multicolumn{4}{|c|}{$\begin{array}{c}\text { Specific binding of }{ }^{125} \text { I-labelled rat FSH to fixed } \\
\text { weight of homogenate }\end{array}$} & \multirow{3}{*}{\multicolumn{2}{|c|}{$\begin{array}{l}\text { Maximum binding } \\
\text { capacity from } \\
\text { Scatchard plots } \\
\text { (pg }{ }^{125} \text { I-labelled rat } \\
\text { FSH/testis) }\end{array}$}} \\
\hline & \multicolumn{2}{|c|}{$\begin{array}{l}\text { Combined data using all } \\
\text { concentrations of homogenate }\end{array}$} & \multirow{2}{*}{\multicolumn{2}{|c|}{$\begin{array}{c}\text { At lowest conc. of } \\
\text { homogenate: } \% \text { of added } \\
\text { FSH bound (mean } \pm \text { s.e.m.) }\end{array}$}} & & \\
\hline & \multirow{2}{*}{$\begin{array}{l}\text { After } \\
\text { treatment } \\
\text { as } \% \\
\text { control }\end{array}$} & \multirow{2}{*}{$\begin{array}{l}\text { Significance of } \\
\text { difference from } \\
\text { control }\end{array}$} & & & & \\
\hline & & & Control & CPA-treated & Control & CPA-treated \\
\hline 1 & 126 & $P<0.01$ & $5.1 \pm 0.1$ & $6 \cdot 1 \pm 0.2$ & - & - \\
\hline 2 & 113 & $P>0.05$ & $2.4 \pm 0.2$ & $2.7 \pm 0.1$ & - & - \\
\hline 3 & 131 & $P<0.01$ & $10.3 \pm 0.4$ & $13.0 \pm 0.4$ & - & - \\
\hline 4 & 95 & $P>0.05$ & $11.7 \pm 0.02$ & $11.9 \pm 1.5$ & - & - \\
\hline 5 & - & - & - & - & 756 & 1000 \\
\hline 6 & - & - & 一 & - & 2221 & 2578 \\
\hline 7 & - & - & - & - & 1912 & 3550 \\
\hline
\end{tabular}

Differences in control binding capacity in Exps 5-7 are due mainly to the use of a different batch of iodinated FSH for Exp. 5.

\section{Binding to homogenates of testes of individual animals treated with cyproterone acetate}

In Exps 8-10 (Table 2) homogenates were prepared from the testes of individual treated or control animals, and in all 3 experiments, testes from the treated rats bound more FSH. This effect was statistically significant in Exps 8 and 9 but not in Exp. 10 in which one of the control rats showed uncharacteristically high binding.

\section{Effects of testosterone}

In Exps $11-13$, injection of $500 \mu \mathrm{g}$ testosterone propionate reduced specific binding of FSH by homogenates of pooled testicular tissue $24 \mathrm{~h}$ later. Reductions were small, binding being 91 , 87 and $96 \%$ of binding shown by control homogenates, butoanalysis of variance showed that the $6 \mathrm{PM}$ 
Table 2. Binding of FSH by fixed aliquots of testicular tissue from individual rats treated with cyproterone acetate (CPA) or vehicle alone (controls)

\begin{tabular}{|c|c|c|c|c|c|c|}
\hline \multirow[b]{2}{*}{ Exp. } & \multicolumn{2}{|c|}{ Control animals } & \multicolumn{4}{|c|}{ CPA-treated animals } \\
\hline & $\begin{array}{l}\text { No. } \\
\text { of rats }\end{array}$ & $\begin{array}{l}\text { Specific binding } \\
\text { as } \% \text { of added } \\
\text { FSH } \\
\text { (mean } \pm \text { s.e.m.) }\end{array}$ & $\begin{array}{l}\text { No. } \\
\text { of rats }\end{array}$ & $\begin{array}{c}\text { Specific binding } \\
\text { as } \% \text { of added } \\
\text { FSH } \\
\text { (mean } \pm \text { s.e.m.) }\end{array}$ & $\begin{array}{l}\text { As } \% \text { of binding } \\
\text { in control group }\end{array}$ & $\begin{array}{c}\text { Significance } \\
\text { of } \\
\text { differences } \\
\text { from control } \\
\text { group }\end{array}$ \\
\hline 8 & 3 & $22 \cdot 1 \pm 0 \cdot 3$ & 3 & $24.8 \pm 0.7$ & 112 & $P<0.05$ \\
\hline 9 & 4 & $25 \cdot 6 \pm 0.5$ & 5 & $28.2 \pm 0.4$ & 110 & $P<0.01$ \\
\hline 10 & 5 & $23.9 \pm 6.2$ & 4 & $25.9 \pm 0.8$ & 108 & $P>0.2$ \\
\hline
\end{tabular}

Binding was measured in each animal using $1 / 20$ th of the total testicular tissue. The s.e.m. values represent variation among animals.

reduction summed over all concentrations of homogenate was significant in Exp. $11(P<0.05)$ and Exp. $12(P<0.01)$. In Exp. 13 the overall effect was not significant, but the reduction of binding at the lowest concentration of homogenate was $(P<0.05)$. This reduction in binding/unit weight of tissue was not due to any change in the weight of testicular tissue recovered as this was almost identical in control and treated animals. In Exps 14 and 15 homogenates were prepared from individual treated and control rats and FSH binding was measured using a fixed aliquot of total testicular tissue. In Exp. 14 testosterone propionate caused a significant $(P<0.05)$ reduction in binding to $93 \%$ of the control value but there was no significant effect in Exp. 15 (101\%).

\section{Discussion}

In 9 out of 10 experiments, treatment with $1 \mathrm{mg}$ cyproterone acetate caused an increase in FSH binding $24 \mathrm{~h}$ later. The increase was small but statistically significant in 4 out of the 7 experiments in which significance could be assessed. The remaining 3 experiments (Nos. 5-7) showed increases in apparent receptor numbers ranging from 16 to $86 \%$. The effect was therefore usually small and variable, but demonstrable on all but one occasion. Increases in FSH binding were also observed with more prolonged administration of cyproterone acetate in immature rats but are not reported here as the accompanying changes in testicular weight and probably morphology made interpretation uncertain. Neumann et al. (1975) showed an opposite effect of cyproterone acetate but this was produced by the treatment of adult rats over several weeks.

The short-term effect of cyproterone acetate was presumed to be due to its anti-androgenic effect, although circulating androgen would be expected to be low at this age (Ketelslegers, Hetzel, Sherins \& Catt, 1978). It was therefore anticipated that treatment with androgen would reduce FSH binding, and injection of testosterone propionate was shown to cause a small but statistically significant reduction in 4 out of 5 experiments.

These findings suggest that androgens may tend, directly or indirectly, to reduce the number of FSH receptors in the testes of maturing rats. The effects demonstrated were small under the conditions of these experiments but such an effect might make some contribution to the physiological control of testicular function.

We thank Dr S. H. Hasan and Schering AG, Berlin, for gifts of anti-androgens, and Dr A. F. Parlow and the Rat Pituitary Program of the NIAMDD, U.S.A., for supplies of hormones and antiserum. P.J.O'S. was supported by the M.R.C. 


\section{References}

Elkington, J.S.H., Sanborn, B.M. \& Steinberger, E. (1975) The effect of testosterone propionate on the concentration of testicular and epididymal androgen binding activity in the hypophysectomised rat. Molec. cell. Endocr. 2, 157-170.

Ketelslegers, J.M., Hetzel, W.D., Sherins, R.J. \& Catt, K.J. (1978) Developmental changes in testicular gonadotrophin receptors: plasma gonadotrophins and plasma testosterone in the rat. Endocrinology 103, 212-222.

Louis, H.G. \& Fritz, I.B. (1979) Follicle-stimulating hormone and testosterone independently increase the production of androgen-binding protein by Sertoli cells in culture. Endocrinology 104, 454-461.

Neumann, F., Diallo, F.A., Hasan, S.H., Schenck, B. \& Traore, I. (1975) The influence of pharmaceutical compounds on male fertility. Andrologia 8, 203-235.

O'Shaughnessy, P.J. \& Brown, P.S. (1978) Reduction in FSH receptors in the rat testis by injection of homologous hormone. Molec. cell. Endocr. 12, 9-15.

Sharpe, R.M. \& Shahmanesh, M. (1974) Influence of age and duration of treatment on the effects of testosterone on serum and pituitary FSH levels in male rats. $J$. Endocr. 63, 571-578.

Received 12 May 1980 